\title{
Spatial distribution of Tephrocactus aoracanthus (Lem.) Lem. in relation to shrubs in the hyperarid regions of west-central Argentina
}

\author{
MARTÍN ALMIRÓN* AND EDUARDO MARTÍNEZ CARRETERO \\ Geobotánica y Fitogeografía, Instituto Argentino de Investigaciones de las Zonas Aridas, National \\ Council for Scientific and Technological Research, CC 507, 5500 Mendoza, Argentina (Email: \\ malmiron@lab.cricyt.edu.ar; martinalmiron2000@hotmail.com)
}

\begin{abstract}
The spatial intraspecific and interspecific distribution of Tephrocactus aoracanthus (Lem.) Lem. was studied using univariate and bivariate point pattern analysis, at landscape scale in four different physiographic units and at microscale in terms of the shrubs found in those units. The influence of shrubs on photosynthetically active radiation and on soil temperature under their canopies was analysed. Results show a high environmental variability in light and temperature under shrubs that generally has no influence on the distribution of T. aoracanthus. Apparently, this cactus has great ability to adapt to different conditions of both photosynthetically active radiation and temperature. However, intraspecific distribution was highly clustered in all physiographic units, independently of bushes. Possibly, the mode of seed dispersal and the rooting of cladodes at small scale are the main processes that determine the strong intraspecific clustering of $T$. aoracanthus.
\end{abstract}

Key words: environmental heterogeneity, intra/interspecific association, Wiegand-Moloney's $\mathrm{O}(r)$ statistics.

\section{INTRODUCTION}

The importance of interactions between plants in the structure and composition of plant ecosystems is nowadays widely accepted. In the 1970s and 1980s, most reports focused on negative-type interactions (Yeaton \& Cody 1976; Yeaton 1978; Conell 1983; Schoener 1983); later, in the 1990s and 2000s, focus changed to positive interactions, where at least one species benefits from the presence of another species (Callaway \& Walker 1997; Hacker \& Gaines 1997). Probably, both types of interactions coexist simultaneously, resulting in a dynamic balance (Callaway \& Walker 1997; Holmgren et al. 1997; Tielbörger \& Kadmon 2000) which depends also on the life stages of intervening plants (Valiente-Banuet et al. 1991; Flores-Martínez et al. 1994) and on environmental conditions (Tielbörger \& Kadmon 2000; Armas \& Pugnaire 2005).

Apparently, facilitation increases in situations of stress, whereas negative interactions prevail under more beneficial conditions (Bertness \& Callaway 1994; Callaway \& Walker 1997; Tewksbury \& Lloyd 2001).

In desert environments, the Cactaceae have been reported to be associated with shrubs that attenuate high solar radiation and soil temperature (Franco \& Nobel 1989; Valiente-Banuet \& Ezcurra 1991; Valiente-Banuet et al. 1991; Leirana-Alcocer \&

${ }^{\star}$ Corresponding author.

Accepted for publication March 2012.

(C) 2012 The Authors

Austral Ecology (C) 2012 Ecological Society of Australia
Parra-Tabla 1999; Carrillo-García et al. 2000; Mandujano et al. 2002, Almirón \& Martínez Carretero 2010), to improve moisture and nutrient content (Carrillo-García et al. 2000; Méndez et al. 2004), to protect seedlings against herbivory (Valiente-Banuet \& Ezcurra 1991) and to provide preferential sites for seed deposition (De Viana et al. 2000). On the other hand, allelopathic effects (De Viana et al. 2000; Cazón et al. 2002) and competition for resources (McAuliffe 1984; Franco \& Nobel 1989; Flores-Martínez et al. 1994) were detected between shrubs and cacti.

In the Bolivian Prepuna, López and Valdivia (2007) found that the type of growth in cacti determines their dependence on shrubs, suggesting that columnar cacti grow exclusively under shrubs whereas opuntioid cacti, although more successful beneath shrubs, can likewise develop in open areas.

The genus Tephrocactus consists of seven species characterized by plants with lax branches formed with several overlapping spherical cladodes connected by fragile joints. This genus is endemic of the central west of Argentina. All species in this genus grow in very dry, rocky or sandy, soils and altitudinally are distributed between 500 and $2500 \mathrm{~m}$ (Kiesling 2003).

Tephrocactus aoracanthus (Lem.) Lem., like other opuntioids, has delicately articulated stems that allow its vegetative reproduction through cladode fall and subsequent rooting from areolar meristematic tissue (Bobich \& Nobel 2001; Mandujano et al. 2007), avoiding the critical germination phase (Mandujano et al. 1998; Mauseth 2006).

doi:10.1111/j.1442-9993.2012.02385.x 
No study has thus far addressed the interaction between cacti of the same species; moreover, the spatial distribution pattern of individuals in natural populations of $T$. aoracanthus is likely influenced by density-dependent processes, considering physiographic units and the environmental variability associated with each of them. On this account, the present study was directed to determine both associations (intraspecific and interspecific), using the spatially explicit technique proposed by Wiegand and Moloney (2004).

Because both biotic and abiotic factors contribute to environmental heterogeneity in arid ecosystems (Zavala-Hurtado 1982), and as spatial distribution is the long-term result of intraspecific and interspecific interactions, the objective of this study was to analyse the intraspecific interactions among individuals of the opuntioid cactus species $T$. aoracanthus and the interspecific interactions between T. aoracanthus and all shrub species observed within four different physiographic units (geotopes) in the central Monte desert, attempting to elucidate the following question: how environmental heterogeneity affects, at mesoscale (physiographic unit) and microscale (shrub species), the spatial distribution pattern of T. aoracanthus.

\section{METHODS}

\section{Study area}

The study was conducted at the Matagusanos locality $\left(31^{\circ} 13^{\prime} 17^{\prime \prime} \mathrm{S} 68^{\circ} 39^{\prime} 7^{\prime \prime} \mathrm{W}\right)$ San Juan Province, Argentina. Average annual precipitation is $116.5 \mathrm{~mm}, 72 \%$ occurring during the summer period. Mean annual temperature is $17.2^{\circ} \mathrm{C}$, with an absolute maximum of $42.8^{\circ} \mathrm{C}$ and an absolute minimum of $-7.3^{\circ} \mathrm{C}$ (Servicio Meteorológico Nacional 1958). The shrubland is the dominant physiognomy, with an average plant cover of $20 \%$. Dominant species are Larrea cuneifolia Cav., Bulnesia retama (Gillies ex Hook. \& Arn.) Griseb., Zuccagnia punctata Cav., Larrea divaricata Cav., Bougainvillea spinosa (Cav.) Heimerl, Lycium tenuispinosum Miers and Cercidium praecox (Ruiz \& Pav.) Burkart \& Carter, among others.

At the working scale, the landscape is heterogeneous with sandy and rocky plains and hillsides with east and west exposure, both affected significantly by water erosion.

\section{Sampling design}

To analyse the effect of environmental heterogeneity, the spatial distribution of $T$. aoracanthus was assessed in four physiographic units (at geotope level): alluvial plain (AP), sandy plain (SP), east-exposed hillside $(\mathrm{EH})$ and westexposed hillside (WH).

In each physiographic unit, five plots of $6 \times 10 \mathrm{~m}$ were randomly established. Each plot was split into 1500 squares of $20 \times 20 \mathrm{~cm}$ to obtain the Cartesian coordinates for each cactus as well as the shape, position and size of each shrub, following the methodology of Wiegand et al. (2006) for spatial point pattern analysis for objects of finite size and irregular shape.

Results of the five plots (in each physiographic unit) have been combined in one average graphic function, using the 'combine replicates tool' included in the Programita software. Theoretical issues are developed in Appendix A included in Raventós et al. (2010).

Each cactus was considered as one entity when it had at least one rooted cladode and was independent of other individuals.

To analyse the microenvironment under shrubs, photosynthetically active radiation (PAR) was measured with a digital radiometer: QMSS-S, Apogee, and temperature (Temp) $7 \mathrm{~cm}$ above ground was recorded using rapid response alcohol thermometers. All data have been always recorded on the same shrubs. Measurements were taken at midday and at three positions on the projection of the shadow of bushes: centre, middle and edge of the shadow projection, throughout 1 day in the middle of the spring, summer, autumn and winter periods.

Simultaneously, PAR and Temp were recorded for bare soil in four random points of each plot; the average of these values was taken as reference value.

In each geotope, height and higher and lower diameters of shrub canopies have been measured on all shrubs found within each plot, and the average shrub for each species was established.

Nomenclature of plant species follows that by Zuloaga and Morrone (1999).

\section{Data analysis}

To establish a benchmark for comparison, and to eliminate variation in the readings due to the time elapsed between one plot and another, the values of PAR and Temp recorded under the bushes were subtracted from the average reference value of PAR and Temp recorded for bare soil, on each plot, in each geotope and by season. Thus, one $\triangle \mathrm{PAR}$ and one $\Delta$ Temp value was obtained for each combination of factors (species, geotope and shade position). Subsequently, the average annual value was calculated per shrub species and position in each geotope. In each physiographic unit, the effect of the two factors (shrub species and positions beneath shrubs) on $\triangle \mathrm{PAR}$ and $\triangle \mathrm{Temp}$ and the interaction between them were analysed by using ANOvA factorial and mean separation with Tukey test $(P<0.05)$.

Using the Programita software, we analysed the intraspecific distribution pattern of $T$. aoracanthus in each geotope, comparing the values from the empirical WiegandMoloney's $\mathrm{O}_{11}(r)$ statistics with a null model of complete spatial randomness distribution (Wiegand \& Moloney 2004). To determine $95 \%$ confidence bands, 99 Monte Carlo simulations (Bailey \& Gatrell 1995; Haase 1995) were performed, taking the 5th highest and 5th lowest values as confidence limits (Wiegand et al. 2000). Graphically, if the empirical distribution falls within the confidence limits it is assumed that there are no significant differences with respect to the theoretical distribution model; values distributed above the 
upper confidence limit indicate spatial aggregation and values below the lower limit indicate a regular (uniform) spatial pattern (Diggle 1983).

The relationship between $T$. aoracanthus and shrubs (intraspecific relationship) was analysed using the null model 'Toroidal shift' (Wiegand et al. 2006), in order to preserve the possible intraspecific distribution pattern of T. aoracanthus, as well as the shape, size and position of the bushes.

\section{RESULTS}

Composition, height and average coverage of shrub species found on the plots were different in all four geotopes (Table 1).

At low-slope sites (AP and SP), ANOvA showed significant differences for $\triangle \mathrm{PAR}$ and $\triangle \mathrm{Temp}$ between the factors 'species' and 'position' (Tables 2,3

Table 1. Characterization of physiographic units and shrub species found on the plots

\begin{tabular}{|c|c|c|c|c|c|c|}
\hline Physiographic unit & Shrub species & $\mathrm{H}$ & $\mathrm{HD}$ & LD & $\mathrm{C}$ & $\begin{array}{l}\text { Specific relative } \\
\text { frequency }(\%)\end{array}$ \\
\hline \multicolumn{7}{|l|}{ Alluvial plain (AP) } \\
\hline Slope: $3 \%$ & Bulnesia retama & 1.90 & 3.80 & 3.40 & 10.15 & 3.80 \\
\hline Soil: rocky & Bougainvillea spinosa & 1.00 & 1.80 & 0.95 & 1.51 & 3.60 \\
\hline \multirow[t]{2}{*}{ Shrub cover: $25 \%$} & Lycium tenuispinosum & 0.86 & 1.28 & 0.80 & 0.80 & 1.90 \\
\hline & Larrea cuneifolia & 0.80 & 1.18 & 0.92 & 0.97 & 90.70 \\
\hline \multicolumn{7}{|l|}{ Sandy plain (SP) } \\
\hline Slope: $2-3 \%$ & B. retama & 2.43 & 3.57 & 3.15 & 8.79 & 12.50 \\
\hline Soil: fine sands & Cercidium praecox & 1.90 & 3.00 & 1.80 & 4.24 & 4.20 \\
\hline \multirow[t]{2}{*}{ Shrub cover: $14 \%$} & L. cuneifolia & 0.85 & 1.03 & 0.70 & 0.60 & 12.50 \\
\hline & Larrea divaricata & 0.95 & 1.13 & 1.00 & 1.00 & 70.80 \\
\hline \multicolumn{7}{|l|}{ East hillside $(\mathrm{EH})$} \\
\hline Slope: $50 \%$ & C. praecox & 1.40 & 5.20 & 1.80 & 7.35 & 3.00 \\
\hline Soil: heterometric clasts & L. cuneifolia & 0.71 & 1.14 & 0.88 & 0.90 & 84.80 \\
\hline Shrub cover: $15 \%$ & Zuccagnia punctata & 1.47 & 2.03 & 1.63 & 2.68 & 12.20 \\
\hline \multicolumn{7}{|l|}{ West hillside (WH) } \\
\hline Slope: $50 \%$ & L. cuneifolia & 0.98 & 1.42 & 1.06 & 1.29 & 55.60 \\
\hline $\begin{array}{l}\text { Soil: rocky with gravels } \\
\text { Shrub cover: } 36 \%\end{array}$ & Z. punctata & 1.62 & 2.23 & 2.00 & 3.74 & 44.40 \\
\hline
\end{tabular}

$\mathrm{H}$ (height), HD (high crown diameter) and LD (low crown diameter) are expressed in metres. C (shrub cover) is expressed in square metres.

Table 2. ANOva of $\Delta \mathrm{Temp}$ and $\triangle \mathrm{PAR}$ in the four physiographic units, with respect to the factor shrub species

\begin{tabular}{|c|c|c|c|c|}
\hline Shrubs in each physiographic unit & \multicolumn{2}{|c|}{$\overline{\mathrm{X}} \Delta \mathrm{Temp}\left({ }^{\circ} \mathrm{C}\right)$} & \multicolumn{2}{|c|}{ 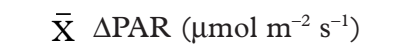 } \\
\hline Alluvial plain & \multicolumn{2}{|c|}{$(F: 24.19 ; P<0.0001)$} & \multicolumn{2}{|c|}{$(F: 3.25 ; P<0.022)$} \\
\hline Larrea cuneifolia & 1.55 & a & 1022.52 & $\mathrm{ab}$ \\
\hline Lycium tenuispinosum & 1.77 & a & 847.04 & $\mathrm{a}$ \\
\hline Bougainvillea spinosa & 2.33 & a & 838.02 & $\mathrm{a}$ \\
\hline Bulnesia retama & 4.89 & $\mathrm{~b}$ & 1389.21 & $\mathrm{~b}$ \\
\hline Sandy plain & \multicolumn{2}{|c|}{$(F: 19.33 ; P<0.0001)$} & \multicolumn{2}{|c|}{$(F: 3.81 ; P<0.01)$} \\
\hline L. cuneifolia & 1.53 & a & 929.06 & $\mathrm{a}$ \\
\hline Larrea divaricata & 1.69 & $\mathrm{a}$ & 924.33 & $\mathrm{a}$ \\
\hline Cercidium praecox & 2.55 & $\mathrm{~b}$ & 967.46 & $\mathrm{ab}$ \\
\hline B. retama & 3.56 & $\mathrm{c}$ & 1201.56 & $\mathrm{~b}$ \\
\hline East hillside & \multicolumn{2}{|c|}{$(F: 10.18 ; P<0.0001)$} & \multicolumn{2}{|c|}{$(F: 1.64 ; P=0.19)$} \\
\hline L. cuneifolia & 1.17 & $\mathrm{a}$ & 1076.05 & a \\
\hline Zuccagnia punctata & 2.14 & $\mathrm{~b}$ & 1187.8 & $\mathrm{a}$ \\
\hline C. praecox & 2.33 & $\mathrm{~b}$ & 935.04 & a \\
\hline West hillside & \multicolumn{2}{|c|}{$(F: 8.81 ; P<0.0032)$} & \multicolumn{2}{|c|}{$(F: 0.64 ; P=0.42)$} \\
\hline L. cuneifolia & 2.01 & a & 1002.62 & a \\
\hline Z. punctata & 2.56 & $\mathrm{~b}$ & 1041.94 & $\mathrm{a}$ \\
\hline
\end{tabular}

Different letters indicate significant differences for Tukey test $(P<0.05)$. PAR, photosynthetically active radiation; Temp, temperature. 
Table 3. ANOva of $\triangle \mathrm{Temp}$ and $\triangle \mathrm{PAR}$ in the four physiographic units, with respect to the factor position beneath shrubs

\begin{tabular}{|c|c|c|c|c|}
\hline Position beneath shrubs in each physiographic unit & \multicolumn{2}{|c|}{$\overline{\mathrm{X}} \Delta \mathrm{Temp}\left({ }^{\circ} \mathrm{C}\right)$} & \multicolumn{2}{|c|}{$\overline{\mathrm{X}} \triangle \mathrm{PAR}\left(\mu \mathrm{mol} \mathrm{m}{ }^{-2} \mathrm{~s}^{-1}\right)$} \\
\hline Alluvial plain & \multicolumn{2}{|c|}{$(F: 3.07 ; P<0.0484)$} & \multicolumn{2}{|c|}{$(F: 13.48 ; P<0.0001)$} \\
\hline Edge & 2.04 & a & 623.62 & a \\
\hline Middle & 2.92 & $\mathrm{~b}$ & 1030.52 & $\mathrm{~b}$ \\
\hline Centre & 2.95 & $\mathrm{~b}$ & 1418.45 & $\mathrm{c}$ \\
\hline Sandy plain & \multicolumn{2}{|c|}{$(F: 12.54 ; P<0.0001)$} & \multicolumn{2}{|c|}{$(F: 31.41 ; P<0.0001)$} \\
\hline Edge & 1.41 & $\mathrm{a}$ & 559.95 & a \\
\hline Middle & 2.59 & $\mathrm{~b}$ & 1068.80 & $\mathrm{~b}$ \\
\hline Centre & 3.00 & $\mathrm{~b}$ & 1388.04 & $\mathrm{c}$ \\
\hline East hillside & \multicolumn{2}{|c|}{$(F: 6.41 ; P=0.0019)$} & \multicolumn{2}{|c|}{$(F: 21.15 ; P<0.0001)$} \\
\hline Edge & 1.08 & $\mathrm{a}$ & 634.19 & $\mathrm{a}$ \\
\hline Middle & 2.16 & $\mathrm{~b}$ & 1121.29 & $\mathrm{~b}$ \\
\hline Centre & 2.40 & $\mathrm{~b}$ & 1443.41 & $\mathrm{c}$ \\
\hline West hillside & \multicolumn{2}{|c|}{$(F: 30.43 ; P<0.0001)$} & \multicolumn{2}{|c|}{$(F: 115.60 ; P<0.0001)$} \\
\hline Edge & 1.35 & $\mathrm{a}$ & 535.59 & a \\
\hline Middle & 2.41 & $\mathrm{~b}$ & 1084.82 & $\mathrm{~b}$ \\
\hline Centre & 3.09 & c & 1446.42 & $\mathrm{c}$ \\
\hline
\end{tabular}

Different letters indicate significant differences for Tukey test $(P<0.05)$. PAR, photosynthetically active radiation; Temp, temperature.

respectively). The interaction between factors was not significant in the low-slope sites (AP: $\triangle \mathrm{PAR}=F: 0.66$; $P=0.6798 ; \Delta$ Temp $=$ AP: $F: 0.43 ; P=0.8587 ;$ SP: $\Delta \mathrm{PAR}=F: 1.19 ; P=0.3102 ; \Delta \mathrm{Temp}=\mathrm{AP}: F: 0.46$; $P=0.8344)$.

At high-slope sites (EH and $\mathrm{WH}$ ), only the factor 'position' was significant for $\triangle \mathrm{PAR}$ and $\Delta \mathrm{Temp}$ (Table 3), while the factor 'species' was significant for $\Delta$ Temp and not significant for $\triangle \mathrm{PAR}$ (Table 2). No significant interaction was observed between factors in the high-slope sites (EH: $\triangle \mathrm{PAR}=F: 0.10 ; P=0.98$; $\Delta$ Temp $=$ AP: $F: 1.13 ; P=0.34 ; \mathrm{WH}: \Delta \mathrm{PAR}=F: 0.02$; $P=0.97 ; \Delta$ Temp = AP: $F: 1.07 ; P=0.34)$.

In all four environments, a gradient of $\triangle \mathrm{PAR}$ and $\Delta$ Temp was observed, which decreased from the centre of the bushes towards the edge of the shadow projection (Table 3). When comparing differences in PAR and Temp between bushes, the soil under B. retama in the low-slope geotopes (AP and SP) was significantly colder and shadier (Table 2).

At the two high-slope sites ( $\mathrm{EH}$ and $\mathrm{WH})$, where no $B$. retama occurred, the shrub casting the most shade was Zuccagnia punctata, although with no significant differences from the partner species (Table 2). With regard to $\Delta$ Temp observed under bushes on 'WH', $Z$. punctata had the highest value, and was significantly different from the codominant species $L$. cuneifolia. On 'EH', the species with the greatest shadow was C. praecox, followed by $Z$. punctata, both significantly different from L. cuneifolia (Table 2).

\section{Intraspecific spatial distribution}

Tephrocactus aoracanthus was found in all geotopes with densities of 2.28 individuals per square metre in 'SP',
0.87 individuals per square metre in 'AP', 1.66 individuals per square metre on ' $\mathrm{EH}$ ' and 0.59 individuals per square metre on 'WH'.

The significant differences observed between the empirical spatial distribution and the null model (complete spatial randomness) in all the physiographic units (Fig. 1) indicate that the probability of finding individuals of $T$. aoracanthus around another is greater than expected by chance.

Tephrocactus aoracanthus forms dense clusters of individuals between different spatial scales (AP: 0-60 cm, SP: 0-100 cm, EH: 0-80 cm and WH: 0-60 cm). From these maximum distances, the absence of significant differences between real data and the theoretical model suggests a random distribution.

\section{Interspecific spatial distribution}

The spatial distribution of $T$. aoracanthus in relation to shrubs showed no significant differences from the Poisson random distribution (Fig. 2). In the 'AP', the density of $T$. aoracanthus was lower than expected by chance for two shrubs: with $B$. retama between 20 and $100 \mathrm{~cm}$ and L. tenuispinosum between 0 and $200 \mathrm{~cm}$. Beneath the canopies of these shrubs (B. retama and L. tenuispinosum), no individuals of $T$. aoracanthus were found in any of the plots in the AP, which demonstrates the negative interaction between these shrubs and cacti. Tephrocactus aoracanthus was positively associated only with $Z$. punctata on 'WH' between 0 and $80 \mathrm{~cm}$, although on ' $\mathrm{EH}$ ' the empirical distribution of $T$. aoracanthus with respect to this shrub was within the confidence interval and therefore can not reject the random distribution of $T$. aoracanthus with respect to $Z$. punctata in 'EH' (Fig. 2).

(C) 2012 The Authors Austral Ecology (C) 2012 Ecological Society of Australia 

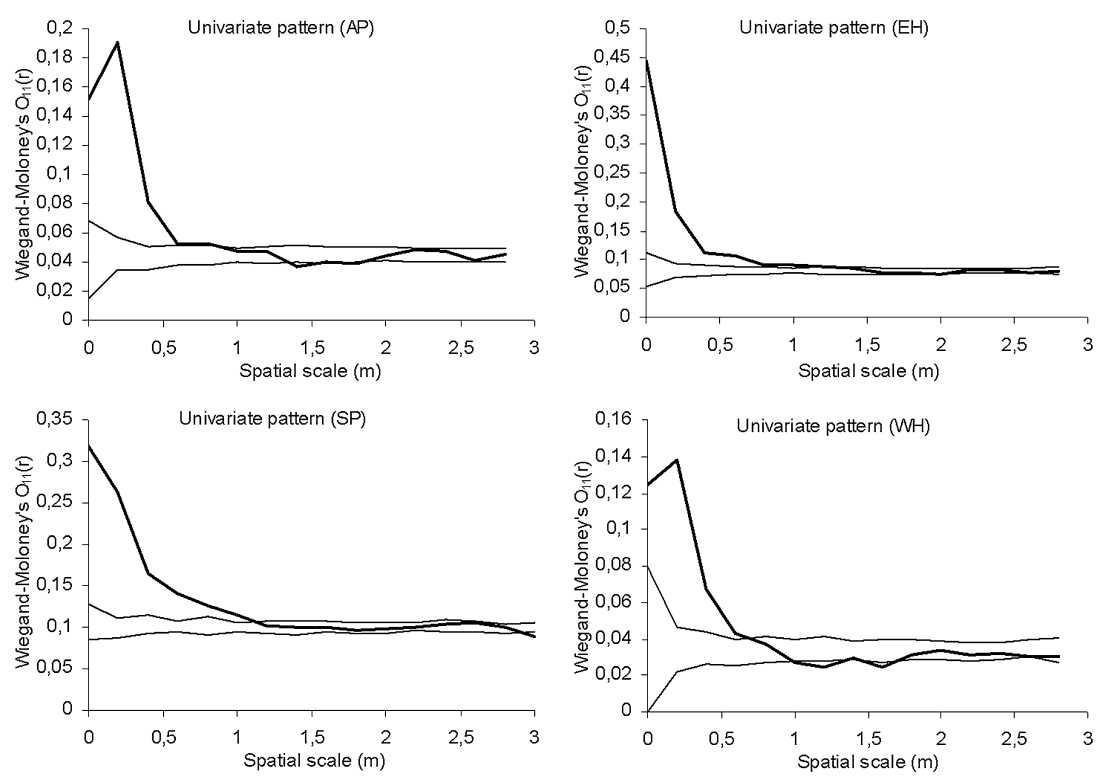

Fig. 1. Analysis of the univariate spatial pattern of Tephrocactus aoracanthus in all physiographic units: alluvial plain (AP), sandy plain (SP), west hillside (WH) and east hillside (EH). Bold line shows the empirical function Wiegand-Moloney's $\mathrm{O}_{11}(r)$ and thin lines show the confidence interval generated by the 5th highest and 5th lowest values of 99 Monte Carlo simulations of random Poisson null model.

\section{DISCUSSION}

Prior studies addressing interactions between plants in arid and semiarid systems have proposed that landscape-scale heterogeneity determines different host species assemblages due primarily to terrain physical variables, such as accumulation of fine sediments and slope, which affect rainwater runoff and infiltration (Yeaton \& Cody 1976; Zavala-Hurtado 1982; Yeaton \& Romero Manzanares 1986). On a lower scale, some authors (Turner et al. 1966; Franco \& Nobel 1989; Valiente-Banuet \& Ezcurra 1991; Mandujano et al. 2002; Méndez et al. 2004; Almirón \& Martínez Carretero 2010) have proposed that shrubs produce a favourable environment regarding bare soil, thus favouring the establishment of cacti. This study provides evidence of the simultaneous relationship between landscape-level perception and diversity of physiographic units that include the environmental variability generated by each shrub species.

Some shrubs, such as species of the genus Larrea that have small evergreen leaves and of B. spinosa and L. tenuispinosum with tiny leaves that fall early, affected very little the photosynthetically active solar radiation and temperature beneath their canopies. These plants are relatively small both in height $(<1 \mathrm{~m})$ and area covered $\left(<1.5 \mathrm{~m}^{2}\right)$ (Table 1) and possess a network of fine branches, generally stunted.

On the other hand, species like Z. punctata, $B$. retama and C. praecox, of greater height and area covered, have numerous densely imbricate stems that prevent the entry of light under their canopies and further reduce soil temperature.

Similarly as found by Yeaton (1978), the studied shrubs were hemispherical, and a light and temperature gradient was observed under them which decreased from the middle to the border of the crown projection area, constituting another source of environmental variation in the microscale system, in keeping with the results obtained by Franco and Nobel (1989).

Despite the marked differences in solar radiation and temperature between shrubs and bare soil, the distribution of $T$. aoracanthus was in general not associated with shrubs. It was only negatively associated with $B$. retama and L. tenuispinosum in the $\mathrm{AP}$ and positively related to $Z$. punctata on WH.

In the $\mathrm{AP}$, under $B$. retama, the soil was cooler and darker (Table 2), likely due to the shape (Table 1) and decumbent position of its dense imbricate stems. Franco and Nobel (1989) proposed that $\mathrm{CO}_{2}$ assimilation in cacti is drastically reduced by some nurse plants that attenuate PAR, consequently affecting host plant fitness. Probably, the exclusion of T. aoracanthus under $B$. retama in the AP is the long-term result of a competitive effect for light or temperature, similar to the spatial dissociation of Lophphora diffusa (Cactaceae) from the colder and shadier environment observed under the canopy of Celtis pallida (Zuñiga et al. 2005).

Instead, the presence of $T$. aoracanthus under B. retama in the SP can be a product of a better-lighted 

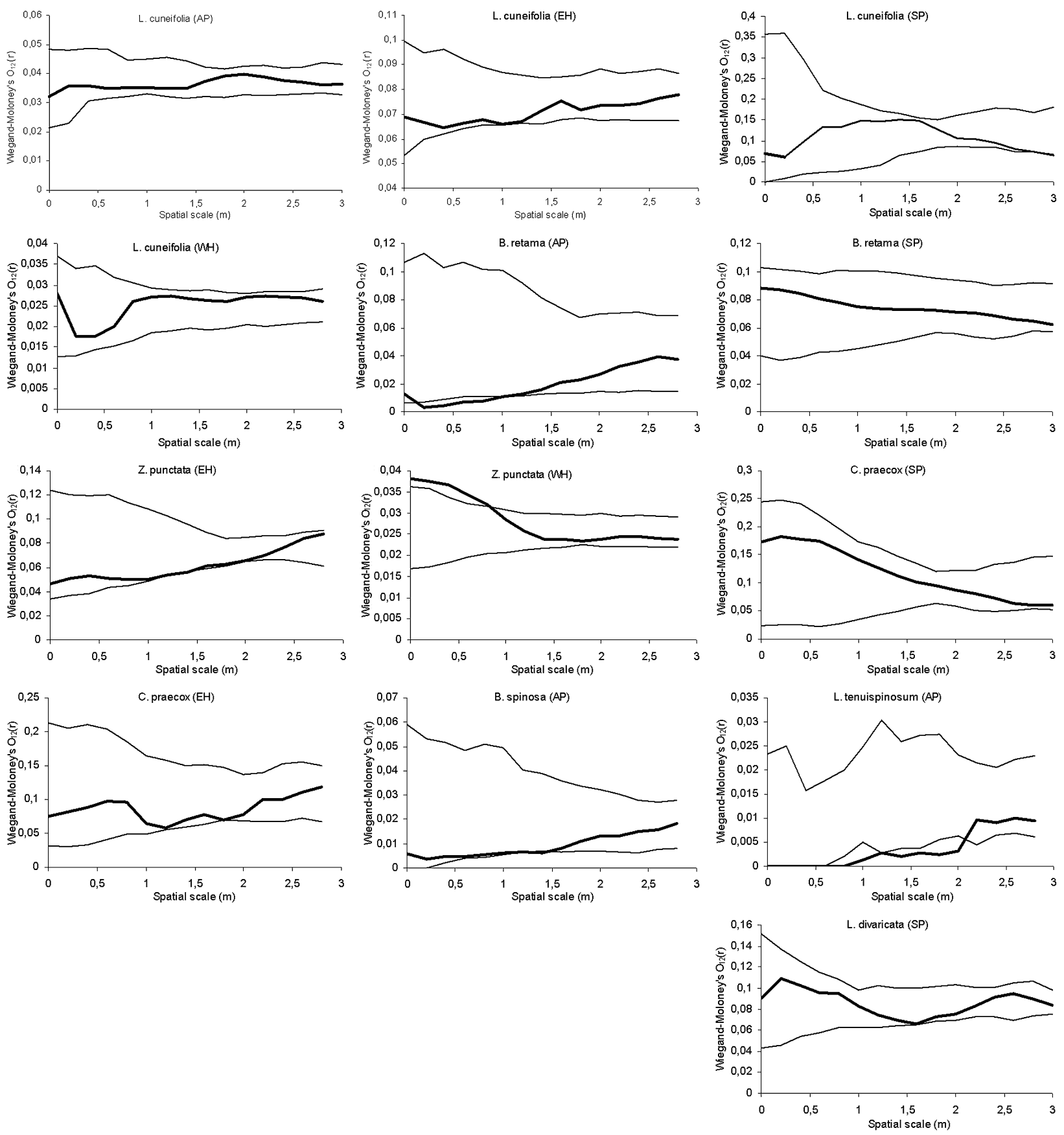

Fig. 2. Analysis of the spatial distribution of Tephrocactus aoracanthus with respect to shrubs found in all physiographic units: alluvial plain (AP), sandy plain (SP), west hillside (WH) and east hillside (EH). Bold line shows the empirical function Wiegand-Moloney's $\mathrm{O}_{12}(r)$ and thin lines show the confidence interval generated by the 5th highest and 5 th lowest values of 99 Monte Carlo simulations of 'Toroidal shift' null model. B. retama, Bulnesia retama; B. spinosa, Bougainvillea spinosa; C. praecox, Cercidium praecox; L. cuneifolia, Larrea cuneifolia; L. divaricata, Larrea divaricata; L. tenuispinosum, Lycium tenuispinosum; Z. punctata, Zuccagnia punctata.

and warmer environment provided by the greater height and lower cover of shrubs (Table 1) and by the upward orientation of their main stems.

The negative association with $L$. tenuispinosum can be mediated by the low architecture of dense spiny stems, which root upon reaching the ground surface generating new plants of agamic origin (Gonzalez Loyarte 1983), and which could act as a physical barrier to fragile seedlings and/or cladodes since this shrub slightly changes radiation and temperature conditions.

(C) 2012 The Authors

Austral Ecology (C) 2012 Ecological Society of Australia 
The results show $Z$. punctata as a shrub that neither generated different radiation and temperature microenvironments nor had different sizes on each of the hillsides (west and east). Possibly, some other variables not analysed in this study (e.g. nutrient content, root interactions, differential water availability) can influence interspecific interactions between T. aoracanthus and this shrub.

On a general level, the distribution of $T$. aoracanthus was mostly independent of shrubs, which concurs with other authors like Reyes-Olivas et al. (2002), Méndez et al. (2004) and López and Valdivia (2007) who postulate that cacti of the opuntioid type can become established on bare soil.

Nonetheless, studies so far conducted on Cactaceae have focused on the relationships between this group and the shrubs that compose the landscape (Valiente-Banuet et al. 1991; Mandujano et al. 1998, 2002; de Viana et al. 2000; Méndez et al. 2004; López \& Valdivia 2007; López et al. 2007), but without the methodological tools used (tests: $\chi^{2}$ and G) allowing detection of intraspecific interactions. In this study it was determined that T. aoracanthus presents a strong and positive intraspecific association in all physiographic units studied and on scales lower than $1 \mathrm{~m}$. From this distance, up to $3 \mathrm{~m}$, the intraspecific distribution of cacti was random.

It is likely that in the assemblage of these populations there predominate distance-dependent processes, such as agamic propagation by gravitational fall and by rooting of cladodes which is typical in opuntioids (Bobich \& Nobel 2001; Mandujano et al. 2007) and in this species in particular (Kiesling 1984). In addition, the permanence of seeds on the ground near the parent plant for time periods exceeding 1 year enhances the relevance of future studies explaining the dispersal mechanisms of this species at different scales, from clusters formation and dynamics to colonization of new environments from a landscape perspective.

The method of analysis proposed by Wiegand and Moloney (2004) affords the possibility of detecting relationships among groups of plants occurring in an explicit spatial context with different environmental variables; therefore, its use is suggested for prospective studies related to interactions between plants and their biophysical environment.

\section{ACKNOWLEDGEMENTS}

Thanks to M. Ariza, J. Cáceres and J. Aguilera for assistance in field, N. Horak for the English version and T. Wiegand, $\mathrm{PhD}$ for comments.

(C) 2012 The Authors

Austral Ecology (C) 2012 Ecological Society of Australia

\section{REFERENCES}

Almirón M. \& Martínez Carretero E. (2010) Echinopsis leucantha (Gilles ex Salm-Dick) Walp. (Cactoideae). Interacciones con plantas nodrizas en el Desierto Central Argentino. Multequina $19,77-87$.

Armas C. \& Pugnaire F. (2005) Plant interactions govern population dynamics in a semiarid plant community. F. Ecol. 93, 978-89.

Bailey T. \& Gatrell A. (1995) Interactive Spatial Data Analysis. Longman Scientific and Technical, Harlow.

Bertness M. \& Callaway R. (1994) Positive interactions in communities. Trends Ecol. Evol. 9, 191-3.

Bobich E. \& Nobel P. (2001) Biomechanics and anatomy of cladode junctions for two Opuntia (Cactaceae) species and their hybrid. Am. F. Bot. 88, 391-400.

Callaway R. \& Walker L. (1997) Competition and facilitation: a synthetic approach to interactions in plant communities. Ecology 78, 1958-65.

Carrillo-García A., Bashan Y. \& Bethlenfalvay G. (2000) Resource-island soil and the survival of the gigante cactus, cardón of Baja California Sur. Plant Soil 218, 20714.

Cazón A., De Viana M. \& Gianello J. (2002) Comparación del efecto fitotóxico de aleloquímicos de Baccharis boliviensis (Asteraceae) en la germinación de Trichocereus pasacana (Cactaceae). Ecol. Austral 12, 73-8.

Conell J. (1983) On the prevalence and relative importance of interspecific competition: evidence from field experiment. Am. Nat. 122, 661-96.

De Viana M., Suhring S. \& Manly B. (2000) Application of randomization methods to study the association of Trichocereus pasacana (Cactaceae) with potential nurse plants. Plant Ecol. 156, 193-7.

Diggle P. (1983) Statistical Analysis of Spatial Point Patterns. Academic Press, London.

Flores-Martínez A., Ezcurra E. \& Sánchez-Colón S. (1994) Effect of Neobuxbaumia tetetzo on growth and fecundity of its nurse plant Mimosa luisiana. F. Ecol. 82, 32530.

Franco A. \& Nobel P. (1989) Effect of nurse plants on the microhabitat and growth of cacti. f. Ecol. 77, 870-86.

Gonzalez Loyarte M. (1983) Estudios sobre la erosión en la Formación El Zampal. Serie Científica 29, 13-15.

Haase P. (1995) Spatial pattern analysis in ecology based on Ripley's K-function: introduction and methods of edge correction. F. Veg. Sci. 6, 575-82.

Hacker S. \& Gaines S. (1997) Some implications of direct positive interactions for community species diversity. Ecology 78, 1966-75.

Holmgren M., Scheffer M. \& Huston M. (1997) The interplay of facilitation and competition in plant communities. Ecology 78, 1966-75.

Kiesling R. (1984) Estudios en Cactaceae de Argentina: Maihueniopsis, Tephrocactus y géneros afines (Opuntioideae). Darwiniana 25, 171-215.

Kiesling R. (2003) Flora de San fuan. República Argentina, Vol. II. Estudio Sigma, Buenos Aires.

Leirana-Alcocer J. \& Parra-Tabla V. (1999) Factors affecting the distribution, abundance and seedling survival of Mammillaria gaumeri, an endemic cactus of coastal Yucatán, Mexico. 7. Arid Environ. 41, 421-8.

López R. \& Valdivia S. (2007) The importance of shrub cover for four cactus species differing in growth form in an Andean semi-desert. F. Veg. Sci. 18, 263-70.

doi:10.1111/j.1442-9993.2012.02385.x 
López R., Valdivia S. \& Quintana N. (2007) The role of nurse plants in the establishment of shrub seedlings in the semiarid subtropical Andes. Oecologia 152, 779-90.

McAuliffe J. (1984) Sahuaro-nurse tree associations in the Sonoran Desert: competitive effects of Sahuaros. Oecología 64, 319-21.

Mandujano M., Flores-Martinez A., Golubov J. \& Ezcurra E. (2002) Spatial distribution of three globose cacti in relation to different nurse-plant canopies and bare areas. Southwest. Nat. 47, 162-8.

Mandujano M., Golubov J. \& Huenekke L. (2007) Effect of reproductive modes and environmental heterogeneity in the population dynamics of a geographically widespread clonal desert cactus. Popul. Ecol. 49, 141-53.

Mandujano M., Montaña C., Méndez I. \& Golubov J. (1998) The relative contribution of sexual reproduction and clonal propagation in Opuntia rastrera from two habitats in the Chiuahuan Desert. F. Ecol. 86, 911-21.

Mauseth J. (2006) Structure-function relationships in highly modified shoots of Cactaceae. Ann. Bot. 98, 901-26.

Méndez E., Guevara J. \& Estevez O. (2004) Distribution of cacti in Larrea spp. shrublands in Mendoza, Argentina. F. Arid Environ. 58, 451-62.

Raventós J., Wiegand T. \& de Luis M. (2010) Evidence for the spatial segregation hypothesis: a test with nine-year survivorship data in a Mediterranean fire-prone shrubland. Ecology 91, 2110-20.

Reyes-Olivas A., García-Moya E. \& López-Mata L. (2002) Cacti-shrub interaction in the coastal desert of northern Sinaloa, Mexico. F. Arid Environ. 52, 431-45.

Schoener T. (1983) Field experiments on interespecific competition. Am. Nat. 122, 240-85.

Servicio Meteorológico Nacional (1958) Estadísticas climatológicas 1941-1950. Publicación B1.

Tewksbury J. \& Lloyd J. (2001) Positive interactions under nurse-plants: spatial scale, stress gradients and benefactor size. Oecologia 127, 425-34.

Tielbörger K. \& Kadmon R. (2000) Temporal environmental variation tips the balance between facilitation and interference in desert plants. Ecology 81, 1544-53.
Turner R., Alcorn S., Olin G. \& Booth J. (1966) The influence of shade, soil and water on Saguaro seedling establishment. Bot. Gaz. 127, 95-102.

Valiente-Banuet A., Bolognaro-Cravenna A., Briones O. et al. (1991) Spatial relation between cacti and nurse shrubs in a semi-arid Environment in central Mexico. F. Veg. Sci. 2, $15-20$.

Valiente-Banuet A. \& Ezcurra E. (1991) Shade as a cause of the association between the cactus Neobouxbaumia tetetzo and the nurse plant Mimosa luisana in the Tehuacán Valley, México. F. Ecol. 79, 961-71.

Wiegand K., Florian J. \& Ward D. (2000) Do spatial effects play a role in the spatial distribution of desert-dwelling Acacia raddiana. F. Veg. Sci. 11, 473-84.

Wiegand T., Kissling W., Cipriotti P. \& Aguiar M. (2006) Extending point pattern analysis to objects of finite size and irregular shape. F. Ecol. 94, 825-37.

Wiegand T. \& Moloney K. (2004) Rings, circles and null-models for point pattern analysis in ecology. Oikos 104, 209-29.

Yeaton R. (1978) A cyclical relationship between Larrea Tridentata and Opuntia Leptocaulis in the Northern Chihuahuan Desert. F. Ecol. 66, 651-6.

Yeaton R. \& Cody M. (1976) Competition and spacing in plant communities: the Northern Mohave Desert. F. Ecol. 64, 689-96.

Yeaton R. \& Romero Manzanares A. (1986) Organization of Vegetation Mosaics in the Acacia Schaffneri-Opuntia Streptacantha association, Southern Chihuahuan Desert, Mexico. f. Ecol. 74, 211-17.

Zavala-Hurtado J. A. (1982) Estudios ecológicos en el valle semiárido de Zapotitlán, Puebla. I. Clasificación numérica de la vegetación basada en atributos binarios de presencia o ausencia de las especies. Biotica 7, 99-120.

Zuloaga F. \& Morrone O. (1999) Catálogo de las PlantasVasculares de la República Argentina. II. Dicotyledoneae (AcanthaceaeEuphorbiaceae) y (Fabaceae-Zygophyllaceae). Missouri Botanical Garden, St. Louis.

Zuñiga B., Malda G. \& Suzán M. (2005) Interacciones Plantanodriza en Lophophora diffusa (Cactaceae) en un desierto subtropical de México. Biotrópica 37, 351-6. 